\title{
Extraction of Fe(III) Ions through MDLM System Containing TOPO as Carrier
}

\section{Ramazan DONAT $^{1 *}$, Ömür DURMAZ ${ }^{1}$}

\begin{abstract}
In this study, the transport and mechanism of Fe(III) ions in acidic solution were investigated by using TOPO as carrier dissolved in kerosene with multi-drop membrane system. The parameters which are important in the transport of $\mathrm{Fe}(\mathrm{III})$ ions and their effects on the extraction process have been studied. These parameters are the effects of concentration of $\mathrm{HCl}$ solutions of donor phase, concentration of $\mathrm{NaCl}$ solutions of acceptor phase, concentration of TOPO solution of organic phase, transfer rate of organic phase, and temperature of the system. The optimum conditions for extraction of $\mathrm{Fe}$ (III) ions was conducted as $2.00 \mathrm{M}$ of $\mathrm{HCl}$ and $100 \mathrm{mgL}^{-1} \mathrm{Fe}$ (III) ions for donor phase, $1.5 \times 10^{-2} \mathrm{M}$ of TOPO, $2.00 \mathrm{M} \mathrm{NaCl}$ of acceptor phase, $50 \mathrm{mLmin}^{-1}$ of flux rate at $298.15 \mathrm{~K}$. Over time, the reduction curves of the $\mathrm{Fe}(\mathrm{III})$ ions in the donor phase showed good agreement with the experimental data on the organic and acceptor phases. The activation energy was determined as 25.79 $\mathrm{kJmol}^{-1}$ and the extraction of $\mathrm{Fe}(\mathrm{III})$ ions was carried out by an intermediated-controlled process.
\end{abstract}

Keywords: Iron, MDLM system, Extraction, TOPO

\footnotetext{
${ }^{1}$ Ramazan DONAT (Orcid ID: 0000-0002-5701-5030), Ömür DURMAZ (Orcid ID: 0000-0002-5390-9352), Pamukkale University, Faculty of Science and Arts, Chemistry Department, 20070 Denizli, TURKEY

*Sorumlu Yazar: Ramazan DONAT, e-mail: rdonat@pau.edu.tr

Bu çalışma Ömür DURMAZ’ın Doktora tezinin bir bölümüdür. Makale 05-08/06/2014 tarihleri arasında Denizlide düzenlenen IV. Fiziksel Kimya Kongresinde sözlü bildiri olarak sunulmuştur. 


\section{INTRODUCTION}

Iron, $\mathrm{Fe}(\mathrm{II})$ and $\mathrm{Fe}(\mathrm{III})$ ions are found in different rock and soil minerals and are the fourth most abundant element of the earth's crust (Bagheri, et al., 2000). Iron is one of the most indispensable trace elements for the human body can be found in many enzymes, proteins structure, and acts as cofactor for many cellular metabolism reactions. Iron helps to transport oxygen to all tissues by forming hemoglobin, and deficiencies and excesses in the human body result in various pathological disorders (Nandre et al., 2014).

Iron plays a role in photosynthesis and important growth nutrients for phytoplankton in the open ocean. Totally dissolved iron in natural water systems varies from $0.20 \mathrm{nmolL}^{-1}$ on the ocean surface to $400 \mu \mathrm{molL}^{-1}$ in polluted urban areas (Bagheri, et al, 2000). Unlikely to other fundamental trace elements the human body has capability to bank excess iron to use whenever required, whereas an excess exposure to iron becomes highly toxic because of the formation of reactive oxygen intermediates that result in peroxidative harm to vital cellular structures (Alguacil et al., 2010).

Precipitation as jarosite, goethite or hematite is a general method for the removal of $\mathrm{Fe}$ (III) ions from aqueous solutions, solvent extraction is also used for the same purpose (Pośpiech et al., 2005). Among them, membrane technologies especially liquid membranes show their importance (Alguacil and Alonso, 2000).

The separation technique that is still developing today is a technique based on liquid membranes. The liquid membrane emulsion technique is known as a double emulsion system. This technique provides a wide and potential range of applications due to its characteristics, such as ease of operation, relatively cheap and efficient operational costs (extraction and backextraction stages in one stage) with high selectivity, and requires a fast extraction time (Hamzah et al., 2011). This technique has been used by many researchers in the separation (extraction) of various types of compounds and metals (Matsumoto, 1998; Djunaidi and Haris, 2003; Kargari et al., 2004; Othman et al., 2006; Gheorge et al., 2008; Kondo and Basuki, 2008; Praipruke et al., 2012). The extraction mechanism of the liquid membrane technique is that the molecule or ion to be extracted is initially in the external phase and diffuses to the internal phase through the membrane phase with the aid of the solute carrier molecule (chelating) in the membrane phase.

$\mathrm{Fe}$ (III) ions can be transported by using different organic carrier for liquid membrane systems such as organophosphorus acid derivatives of di-(2-ethylhexyl) phosphonic acid (PC-88A) and di-(2-ethylhexyl) phosphoric acid ( $\mathrm{D}_{2}$ EHPA) (Jayachandran and Dhadke, 1997; Lupi and Pilone, 2000; Biswas and Begum, 2001). The neutral carriers used are methyl isobutyl ketone (MIBK), tributyl phosphate (TBP), trioctyl phosphine oxide (TOPO), and Cyanex 923 (Saji et al., 1999; Alguacil and Martinez, 2000; Gupta et al., 2001; Saji and Reddy, 2001; Fu et al., 2004,). Especially, TOPO is applied for supported liquid membrane system (Alguacil and Alonso, 2000).

The multi-drop liquid membrane (MDLM) system is one of the liquid membrane techniques. In the recent years, the extraction of heavy metals by MDLM system has been the subject of many studies. Contribution in this regard has been made by many researchers who have extracted number of heavy metal ions, such as Th(IV) (Tavşan, 2012), Cu(II) (Donat et al. 2017, Eyice, 2013), Mo(VI) (Donat et al., 2015) U(VI) (Erden et al., 2015), Pb(II) (Durmaz and Donat, 2016), Cr(VI) (Tuncay, 2017), Cd(II) (Donat and Eyice, 2018), Zn(II) (Erden and Donat, 2018), Mn(II) (Donat et al., 2018) and $\mathrm{Fe}(\mathrm{III})$ (in this study). MDLM technique is the most popular membrane system and has been used with great success.

The present investigation covers the single extraction of $\mathrm{Fe}(\mathrm{III})$ ions over different 
temperatures, $\mathrm{pH}$ of donor phase, concentrations of acceptor phase and organic carrier from a dilute aqueous solution across MDLM system with TOPO as organic carrier. This MDLM technique involves the extraction of $\mathrm{Fe}(\mathrm{III})$ ions across the organic membrane via their concentration gradient by a suitable carrier dissolved in a water immiscible organic diluent that is kerosene for this study.

\section{MATERIALS AND METHODS}

\section{Chemicals and solutions used in the study}

Refined kerosene (supplied by indigenously Turkish Petroleum Refineries Company) was used as diluent to obtain the desired concentrations of TOPO organic carrier. Iron(III) nitrate, TOPO, potassium thiocyanide, and all other chemicals were obtained from Merck.

Stock solution of $500 \mathrm{mgL}^{-1} \mathrm{Fe}$ (III) ions was prepared by $\mathrm{Fe}\left(\mathrm{NO}_{3}\right)_{3} \cdot 9 \mathrm{H}_{2} \mathrm{O}$, and respectively and diluted to the required concentrations when necessary. 0.10 M KSCN was prepared by dissolving $2.43 \mathrm{~g}$ in water and made up to $250 \mathrm{~mL} 7.50 \times 10^{-3} \mathrm{M}$ TOPO was diluted by kerosene from the stock solution. 2.00 $\mathrm{M}$ of $\mathrm{HCl}$ in donor phase and $2.00 \mathrm{M}$ of $\mathrm{NaCl}$ solution in acceptor phase was applied.

\section{Procedure}

The MDLM system was designed by Pamukkale University academics Halil Cetişli and Ramazan Donat. The scheme of MDLM system is shown in Fig. 1. The porous glass was applied to the bottom of the reactor for a more homogeneous distribution of the droplets. The organic phase is circulated in both reactors with a peristaltic pump and forms multi droplets through the pores under both reactors. The organic phase passes from either phase as bubbles and mixes the donor and acceptor phase. The organic ligands carry target metals from donor phase to stripping phase, leave it there and then turn back to donor phase again in order to re-carry the target metals(Donat et al., 2015; Erden et al., 2015).

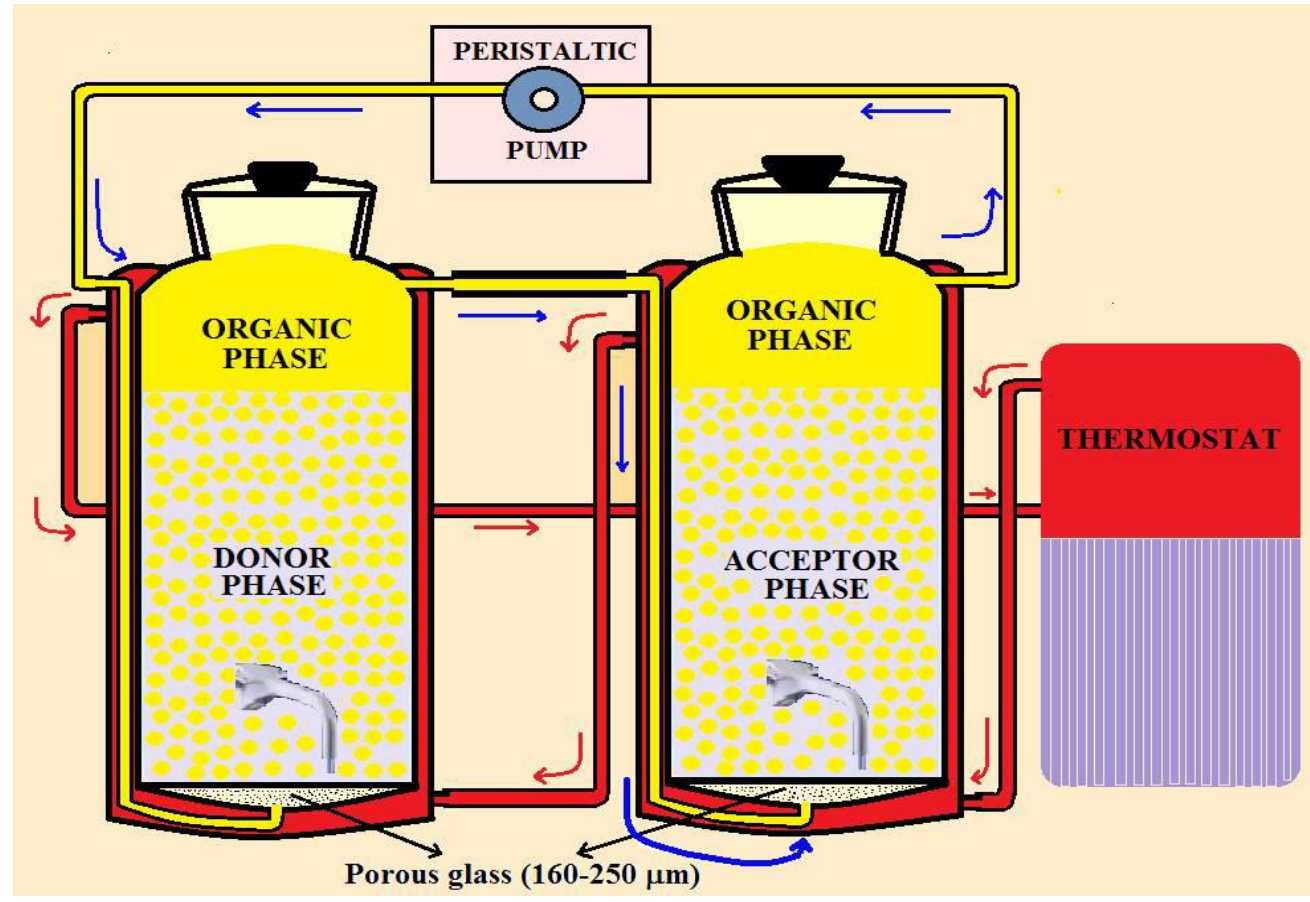

Figure 1. Picture of the measuring set with flowing MDLM. 
CircuWCR P8 Wise model refrigerated bath circulator was used to keep the temperature constant of MDLM system. BT30-2J model peristaltic pump device was used to transport and flow the organic phase through the donor and acceptor phase.

\section{Kinetic analysis}

The kinetics of transport was investigated by the model used, where the reduced concentration were used. For practical reasons, the donor $\left(C_{\mathrm{d}}\right)$, organic $\left(C_{\mathrm{m}}\right)$ and acceptor $\left(C_{\mathrm{a}}\right)$ symbols were used for the $\mathrm{Fe}(\mathrm{III})$ ions in the excess of MDLM system $\left(C_{o}=C_{d}+C_{m}+C_{a}\right.$ obviously being unity).

Where $C_{0}$ is initially concentration of $\mathrm{Fe}(\mathrm{III})$ ions. $C_{\mathrm{d}}, C_{\mathrm{m}}$ and $C_{\mathrm{a}}$ indicate the $\mathrm{Fe}(\mathrm{III})$ ions concentrations in the donor, organic and acceptor phases at time $(\mathrm{t}>0)$.

Transport of $\mathrm{Fe}(\mathrm{III})$ ions obeys the kinetics law of two consecutive irreversible first-order reactions according to the kinetic scheme (Patel et al., 2009).

$$
C_{D} \stackrel{k_{1}}{\rightarrow} C_{M} \stackrel{k_{2}}{\rightarrow} C_{A}
$$

where the symbols of $C_{\mathrm{D}}, C_{\mathrm{M}}$, and $C_{\mathrm{A}}$ are $\mathrm{Fe}$ (III) ions in the donor, organic, and acceptor phases, respectively (Donat et al., 2015).

The integrated forms of $C_{d}, C_{m}$ and $C_{a}$ are given in equilibrium (2-4).

$$
\begin{aligned}
& C_{d}=C_{o} \cdot e^{-k_{1} t} \\
& C_{m}=C_{o}\left(\frac{k_{1}}{k_{2}-k_{1}}\right)\left(e^{-k_{1} t}-e^{-k_{2} t}\right) \\
& C_{a}=C_{o}\left[1-\frac{k_{2} e^{-k_{1} t}-k_{1} e^{-k_{2} t}}{k_{2}-k_{1}}\right]
\end{aligned}
$$

According to Eq. (5), the value of $C_{\mathrm{m}}$ in experimental studies increases at first, then decreases with time. Furthermore $C_{\mathrm{m}}$ value has a maximum which allows for the calculation of maximum values of $\mathrm{Fe}(\mathrm{III})$ ions concentration in the organic phase and time, according to the following equations.

$$
t_{\max }=\ln \left(k_{1} / k_{2}\right) /\left(k_{1}-k_{2}\right)
$$

$C_{\mathrm{B}}^{\max }$ values at that time period.

$C_{\mathrm{B}}^{\max }=C_{o}\left(\frac{k_{2}}{k_{1}}\right)^{\frac{k_{2}}{k_{1}-k_{2}}}$

When equations (5) and (6) are combined, the following equation can be obtained:

$k_{2}=-\ln \left(\mathrm{C}_{\mathrm{m}}^{\max } / C_{o}\right) / \mathrm{t}_{\max }$

By considering the first-order time differentiation of equations(2-4) at $t=t_{\max }$, one obtains (Patel et al., 2009);

$\left(\frac{d C_{d}}{d t}\right)_{\max }=-k_{1}\left(\frac{k_{1}}{k_{2}}\right)^{-k_{1} /\left(k_{1}-k_{2}\right)} \equiv J_{d}^{\max }$

$\left(\frac{d C_{B}}{d t}\right)_{\max }=0$

$\left(\frac{d C_{a}}{d t}\right)_{\max }=-k_{2}\left(\frac{k_{1}}{k_{2}}\right)^{-k_{2} /\left(k_{1}-k_{2}\right)} \equiv J_{a}^{\max }$

The maximum membrane input $\left(J_{d}^{\max }\right)$ and output $\left(J_{a}^{\max }\right)$ fluxes values are equal to each other but have reverse signs:

$J_{a}^{\max }=-J_{d}^{\max }$

The process of achieving complex transition states requires energy supplied from outside the system. This energy is called the activation energy. In both endotherm and exothermic reactions, both have a positive activation energy, since the complex transition state has a higher energy level than the reactant.

The kinetics of extractions throughout the MDLM system is defined as a first order reaction in the metal ion concentration (Erden et al., 2015):

$$
\ln \left(C_{\mathrm{o}} / C_{\mathrm{e}}\right)=k t
$$

where $C_{\mathrm{o}}$ is the initial concentration of $\mathrm{Fe}$ (III) ions and $C_{\mathrm{e}}$ is the $\mathrm{Fe}(\mathrm{III})$ ions concentration at a given time in the donor phase respectively. The $k$ values were determined by the plots of $\ln \left(C_{\mathrm{o}} / C_{\mathrm{e}}\right)$ vs. time. 
The activation energy values were obtained from the Arrhenius equation by using the membrane input or output flux values at the different temperature. The following arranged version of the equation.

$$
\ln \pm J_{d, a}^{\max }=\ln (A)-\left(E_{a} / \mathrm{RT}\right)
$$

where $J$ is the rate constant, $A$ is the frequency factor, $E_{\mathrm{a}}$ is the activation energy, $R=8.314 \mathrm{Jmol}^{-1} \mathrm{~K}^{-1}$ is the gas constant, and $T$ is the Kelvin temperature.

Determination of the percentage of extraction of $\mathrm{Fe}$ (III) ions successfully extracted into the organic phase, then measured the amount of $\mathrm{Fe}$ (III) ions still dissociated in the external phase using the spectrophotometer. To know the percentage of extraction of $\mathrm{Fe}(\mathrm{III})$ ions obtained in this research used equation (14) as follows:

$$
\mathrm{E}, \%=\frac{[\mathrm{Fe}(I I I)]_{\text {ini }}-[\mathrm{Fe}(I I I)]_{\text {fin }}}{[\mathrm{Fe}(\mathrm{III})]_{\text {ini }}} \times 100
$$

where $\mathrm{E}, \%$ = percent extraction; $[\mathrm{Fe}(\mathrm{III})]_{\text {ini }}$ $=$ initial concentration of $\mathrm{Fe}(\mathrm{III})$ in the donor phase and $[\mathrm{Fe}(\mathrm{III})]_{\mathrm{fin}}=$ the final concentration of the $\mathrm{Fe}$ (III) ions in the acceptor phase (Donat et al., 2015; Erden et al., 2015).

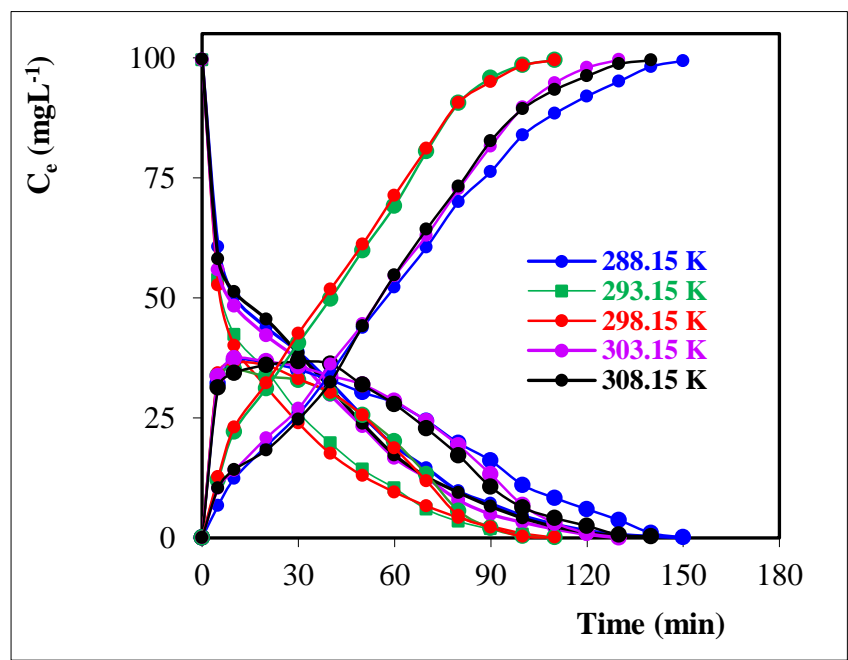

Figure 2. Concentrations of $\mathrm{Fe}(\mathrm{III})$ ions in the donor, acceptor, and organic phases versus time for the experiments carried out at different temperature.

\section{RESULTS AND DISCUSSION}

Effect of temperature on extraction of Fe(III) ions

The MDLM system used throughout this extensive experimental part consisted of $100 \mathrm{~mL}$ of donor, organic and acceptor phase, $100 \mathrm{mgL}^{-1}$ of $\mathrm{Fe}$ (III) ions and $2.00 \mathrm{M}$ of $\mathrm{HCl}$ solution at donor phase, $2.00 \mathrm{M}$ of $\mathrm{NaCl}$ solution as acceptor phase and $7.50 \times 10^{-3} \mathrm{molL}^{-1}$ of kerosene diluted TOPO as organic phase. The transfer rate of TOPO dissolved in kerosene from donor phase to acceptor phase was adjusted to 50 mLmin $^{-1}$. The batch experiment was accomplished at five different temperatures being adjusted by creosote device as 288.15, 293.15, 298.15, 303.15, and 308.15 K. Concentration of $\mathrm{Fe}$ (III) ions for donor, organic and acceptor phase solutions versus time plot is highlighted in Fig. 2. The change of $\ln \left(C_{\mathrm{o}} / C_{\mathrm{e}}\right) \sim$ time plots is illustrated in Fig. 3.

The recovery efficiency of $\mathrm{Fe}(\mathrm{III})$ ions at five temperatures $(288.15-308.15 \mathrm{~K})$ was obtained 99.94, 99.95, 99.95, 99.96 and $99.75 \%$, respectively. Duration varied for different temperatures(288.15-308.15K) as $150,110,110$, 130 , and $140 \mathrm{~min}$, respectively.

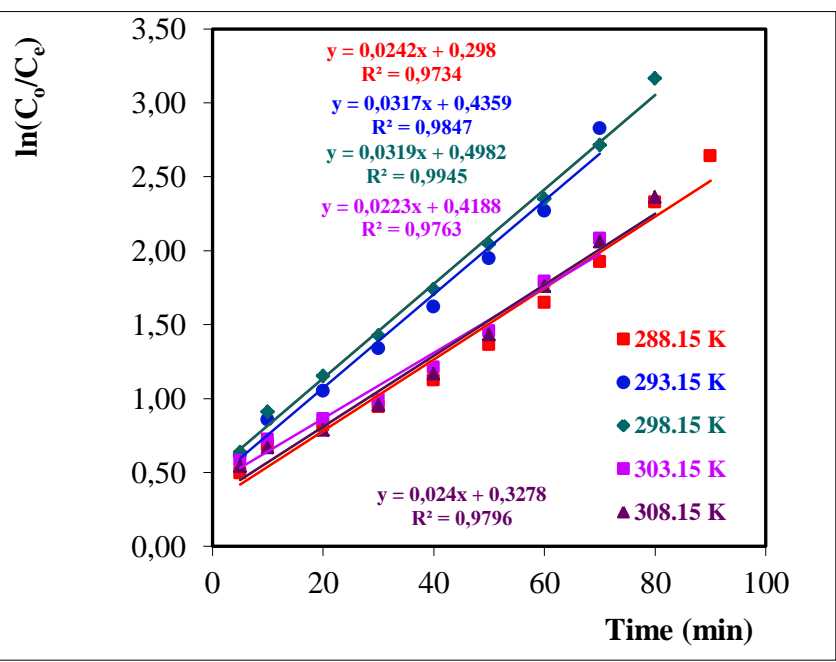

Figure 3. Plots of $\ln \left(C_{\mathrm{o}} / C_{\mathrm{e}}\right)$ vs. time $t$ for the transport of $\mathrm{Fe}(\mathrm{III})$ ions through the MDLM system at five different temperatures. 
Based on the data given in Table 1, reaction rate constant $\left(k_{1}\right)$ differed for varying temperatures $(288.15-308.15 \mathrm{~K})$ as $2.42 \times 10^{-2}$, $3.17 \times 10^{-2}, 3.19 \times 10^{-2}, 2.23 \times 10^{-2}$, and $2.40 \times 10^{-2}$ $\min ^{-1}$, respectively. $k_{1}$ (stands for the reaction rate constant of the reaction takes place at the interface of donor and organic phase) and $k_{2}$ (stands for the reaction rate constant of the reaction takes place at the interface of acceptor and organic phase) elevates due to temperature rise until the temperatures reached to $303.15 \mathrm{~K}$. Moreover, half-life of the reaction and flux rates of donor and acceptor phases $\left(J_{\mathrm{d}}^{\max }\right.$ and $\left.J_{\mathrm{a}}^{\max }\right)$ likewise varied with $k_{1}$ and $k_{2}$ for rising temperature. The change of viscosity of three phases and the rise of mobility of $\mathrm{Fe}$ (III) ions may cause the discrepancy between the data based on 288.15-298.15 K and 303.15-308.15 K. Furthermore, less contact time of organic phase with donor and acceptor phases at higher temperatures may drive the extension of stripping time.

Comparative kinetic parameters of the stripping process of $\mathrm{Fe}(\mathrm{III})$ ions via MDLM system at five different temperatures is exhibited in Table 1.

Table 1. Kinetic parameters of the stripping process of Fe(III) ions via MDLM at five temperatures.

\begin{tabular}{|c|c|c|c|c|c|c|}
\hline Temp. (K) & $k_{1} \cdot 10^{2}\left(\min ^{-1}\right)$ & $k_{2} \cdot 10^{2}\left(\min ^{-1}\right)$ & $t_{1 / 2}(\min )$ & $C_{\mathrm{m}}^{\max }\left(\mathrm{mgL}^{-1}\right)$ & $I_{d}^{\max } \cdot 10^{3}\left(\min _{, a}^{\max }\right.$ & $x .10^{3}(\mathrm{~min}$ \\
\hline 288.15 & 2.42 & 7.20 & 28.63 & 13.00 & 39.01 & -13.93 \\
\hline 293.15 & 3.17 & 7.82 & 21.86 & 12.20 & 38.35 & -17.12 \\
\hline 298.15 & 3.19 & 12.51 & 21.72 & 8.00 & 36.56 & -19.98 \\
\hline 303.15 & 2.23 & 9.80 & 31.07 & 10.00 & 37.35 & -14.42 \\
\hline 308.15 & 2.40 & 3.33 & 28.87 & 30.00 & 36.69 & -10.31 \\
\hline
\end{tabular}

Based on the literature, a process of which activation energy is less than $20 \mathrm{kJmol}^{-1}$ is referred as diffusion-controlled, between 20 $\mathrm{kJmol}^{-1}$ and $50 \mathrm{kJmol}^{-1}$ as intermediatedcontrolled, and more than $50 \mathrm{kJmol}^{-1}$ as chemical reaction-controlled (Chang et al., 2011). Eq. (13) is used for the determination of activation energy. The activation energy of the transportation process by the help of maximum output rates $\left(J_{\mathrm{a}}^{\max }\right)$ and input $\left(J_{\mathrm{d}}^{\max }\right)$ and whether the transportation is diffusion controlled or chemically controlled (Lazarova Z, Boyadzhiev, 1993; Kobya et al., 1997). Activation energy was found out by the slope of $J_{\mathrm{a}}^{\max }$ versus $1 / T$ plot that is given in Fig. 4. The activation energy for transportation of $\mathrm{Fe}$ (III) ions was calculated as $25.79 \mathrm{kJmol}^{-1}$ and this transportation process was found to be intermediate-control process (Erden et al., 2015). 


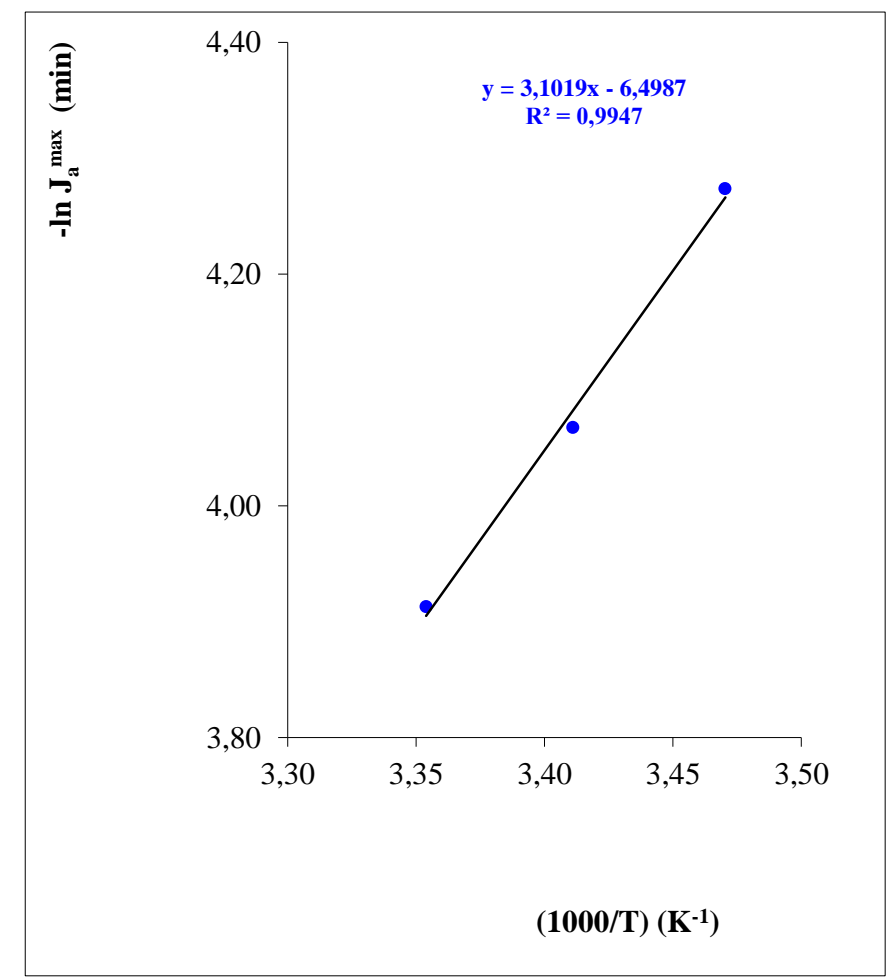

Figure 4. Maximum output rates versus 1/T graph.

\section{The effect of $\mathrm{HCl}$ concentration in the donor phase}

The extraction behavior of $\mathrm{Fe}(\mathrm{III})$ ions by TOPO across MDLM system was investigated through different concentrations $(0.50,1.00$, $1.50,2.00,2.50$, and $3.00 \mathrm{M}$ ) of $\mathrm{HCl}$ solution of donor phase at $298.15 \mathrm{~K}$. The extraction was performed through the concentration of acceptor phase as $2.00 \mathrm{M} \mathrm{NaCl}$, concentration of TOPO as $7.50 \times 10^{-3} \mathrm{M}$, the volume of feed, organic and stripping solutions as $100 \mathrm{~mL}$ and the transfer rate of the peristaltic pump fixed as $50 \mathrm{mLmin}^{-1}$.

$\mathrm{Fe}$ (III) concentration of feed, membrane and acceptor phase solutions against time plot is reported in Fig. 5. Data based on different $\mathrm{HCl}$ concentration of donor phase are applied to plot concentrations of $\mathrm{Fe}$ (III) ions versus time graphs by the help of each concentration of $\mathrm{Fe}$ (III) ions in the donor, organic and acceptor phase.

According to the Eq. (14), extraction efficiency of $\mathrm{Fe}(\mathrm{III})$ ions for different $\mathrm{HCl}$ concentrations is over $99 \%$ and extraction time for different $\mathrm{HCl}$ concentrations $(0.50-3.00 \mathrm{M})$ is $160,140,130,110,100$, and $90 \mathrm{~min}$, respectively. The extraction and stripping of the $\mathrm{Fe}(\mathrm{III})$ ions treatments conforms to the successive first-order reaction kinetics according to the change of $\ln \left(C_{\mathrm{o}} / C_{\mathrm{e}}\right)$ with the time plots plotted in Figure 6.

For six different concentrations of $\mathrm{HCl}$ solution $(0.50-3.00 \mathrm{M})$ in donor phase, $k_{1}$ is $1.69 \times 10^{-2}, \quad 2.01 \times 10^{-2}, \quad 2.16 \times 10^{-2}, \quad 3.16 \times 10^{-2}$, $3.47 \times 10^{-2}$, and $3.89 \times 10^{-2} \mathrm{~min}^{-1}$, respectively. Increasing concentration also elevated the $k_{1}$ values. 


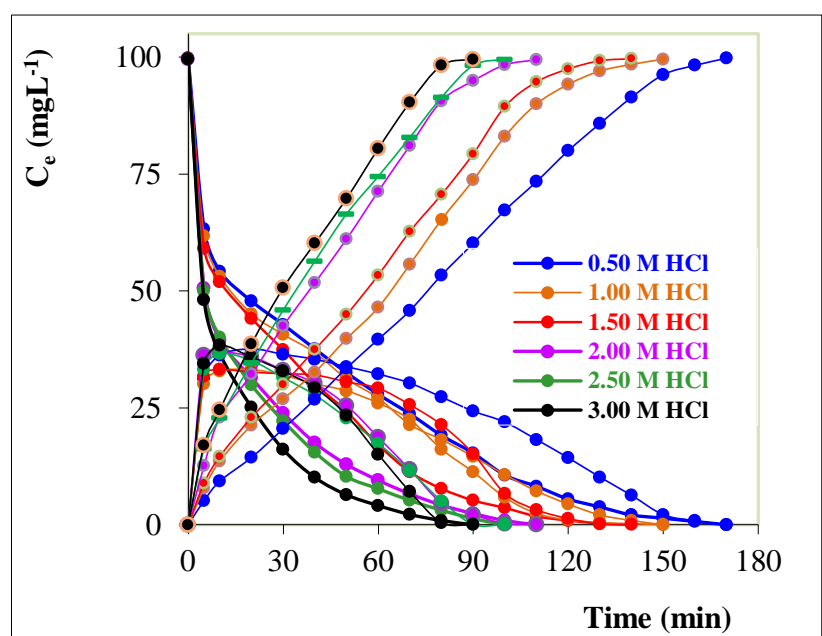

Figure 5. Graph of change of extraction of Fe(III) ions from different $\mathrm{HCl}$ concentration in donor phase against time.

According to these results, the transport and recovery of higher $\mathrm{Fe}$ (III) ions can be obtained effectively at any $\mathrm{HCl}$ concentration.

Alguacil et al., 2000, extracted Fe(III) ions by using different concentrations $(0.20,0.80$, and $2.00 \mathrm{M})$ of $\mathrm{HCl}$ solution in the donor phase and rising $\mathrm{HCl}$ concentration increased the retrieval of $\mathrm{Fe}$ (III) ions. Highest extraction was observed at $2.00 \mathrm{M} \mathrm{HCl}$ solution and at the interface of the donor and organic phase, the reaction given below occurred.

$\mathrm{H}_{(\mathrm{aq})}^{+}+\mathrm{FeCl}_{4(a q)}^{-}+2 \mathrm{~L}_{(\mathrm{org})} \rightleftarrows \mathrm{HFeCl}_{4} \cdot \mathrm{L}_{2(\mathrm{org})}$

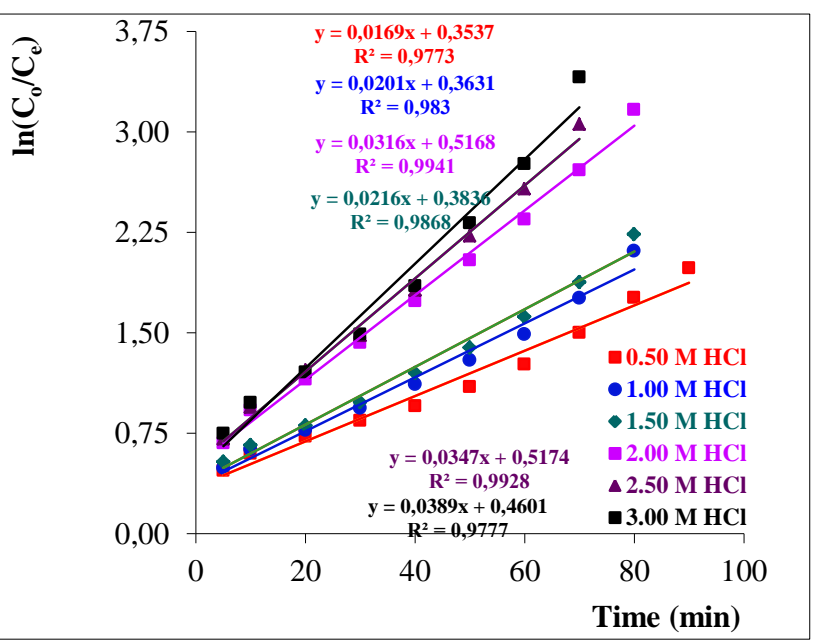

Figure 6. $\ln \left(C_{\mathrm{o}} / C_{\mathrm{e}}\right)$ versus time plots for the single extraction studies of $\mathrm{Fe}(\mathrm{III})$ ions through MDLM system at different $\mathrm{HCl}$ concentrations of donor phase.

Mechanism of the extraction is illustrated in Fig. 7.

\section{The effect of $\mathrm{NaCl}$ concentration in the acceptor phase}

The stripping process of the transportation of $\mathrm{Fe}$ (III) ions plays an important role to complete the extraction. The $\mathrm{NaCl}$ in the stripping solution functioned as a backextractant.

The effect of the acceptor phase concentration on the extraction of $\mathrm{Fe}(\mathrm{III})$ ions was carried out by changing the $\mathrm{NaCl}$ concentration from 0.50 to $3.50 \mathrm{M}$. The other parameters are kept constant during experiments.

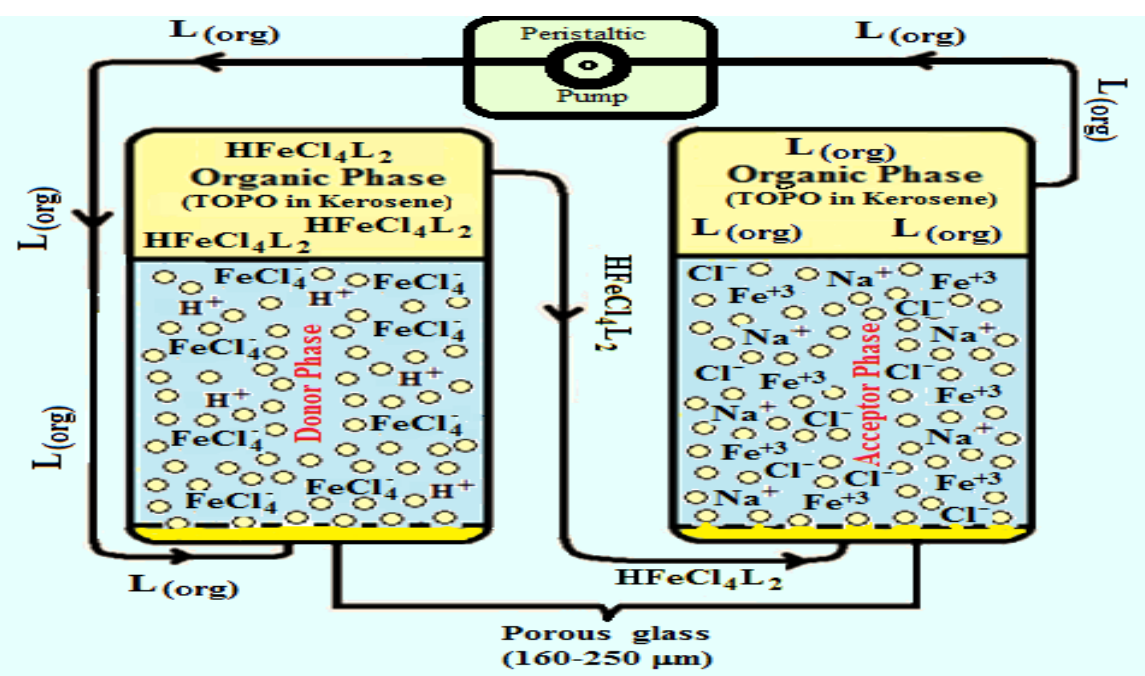

Figure 7. Diagram of transport mechanism of Fe(III) ions in MDLM system 
Fig. 8 shows the kinetic profiles of each phase at different $\mathrm{NaCl}$ concentrations. Extraction efficiency of $\mathrm{Fe}(\mathrm{III})$ ions at different

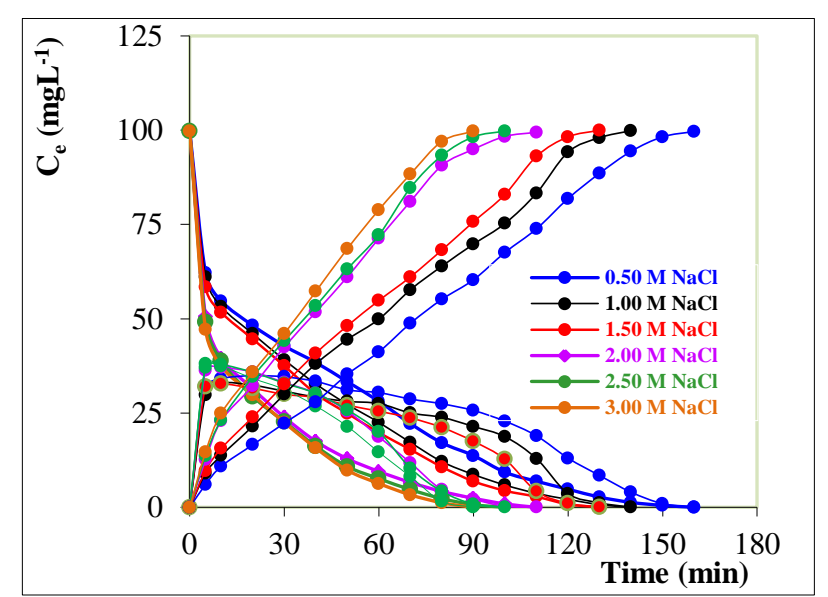

Figure 8. Time evolution of donor, organic acceptor phase for $\mathrm{Fe}(\mathrm{III})$ extraction through MDLM on different $\mathrm{NaCl}$ concentrations in acceptor phase.

$\ln \left(C_{o} / C_{e}\right)$ vs time plots are illustrated in Fig. 9. When the concentration of $\mathrm{NaCl}$ was $0.50-3.50$, by changing transfer time (from 0 to $90 \mathrm{~min}$ ) measured the natural logarithm of the ratio of initial concentration $\left(C_{\mathrm{o}}\right)$ to given time concentration $\left(C_{e}\right)$ of $\mathrm{Fe}(\mathrm{III})$ the kinetic curve can be obtained (see Fig. 9)(Erden et al.,2015). $\ln C_{o} / C_{e} \sim t$ curve line is a good straight line respectively, this shows that the concentration of chlorine ions in the stripping solution don't interfere.

Time of extraction for different receiving phase concentration $(0.50-3.00 \mathrm{M} \mathrm{NaCl})$ is 170 , $150,140,110,100$, and $90 \mathrm{~min}$, respectively. It can be concluded that the rise of $\mathrm{NaCl}$ concentration in the acceptor phase accelerates rate of $\mathrm{Fe}$ (III) ions extraction marginally. Hereby, best results are obtained at $2.00 \mathrm{M} \mathrm{NaCl}$ in the acceptor phase.

\section{The effect of the concentration of TOPO on Fe(III) transport}

To analysis the effect of the TOPO carrier concentration in the organic solution of the pseudo-emulsion phase, several experiments were performed using Comesaña et al., 2011) acceptor phase concentration $(0.50,1.00,1.50$, $2.00,2.50$ and $3.00 \mathrm{M} \mathrm{NaCl}$ ) is $99.96,99.98$, 99.90, 99.95, 99.97, and 99.95\%, respectively.

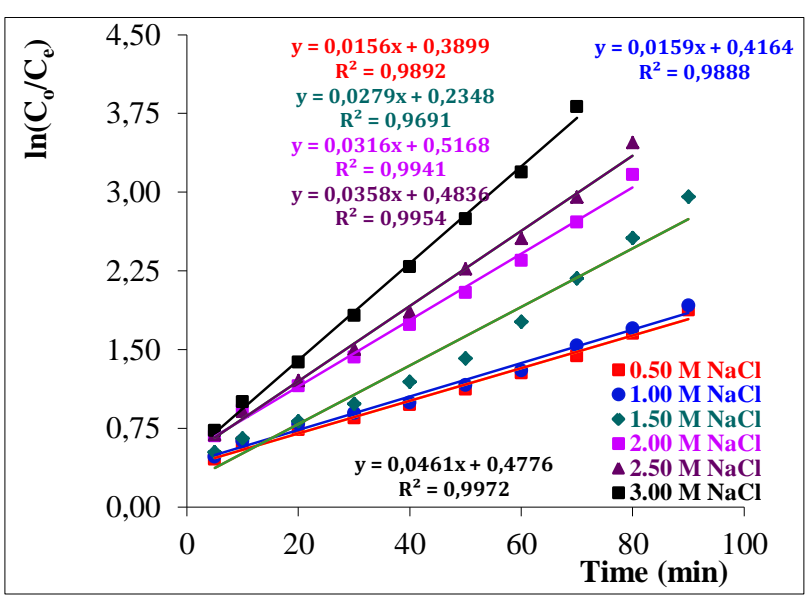

Figure 9. The graph of the extraction kinetics of Fe(III) ions for experiments performed at different $\mathrm{NaCl}$ concentrations (0.5-3.0 M).

donor phase of $100 \mathrm{mgL}^{-1} \mathrm{Fe}(\mathrm{III})$ in $2.0 \mathrm{molL}^{-1}$ $\mathrm{HCl}$ and strip solutions of $2.00 \mathrm{M} \mathrm{NaCl}$ and organic solutions of TOPO carrier $\left(3.75 \times 10^{-3}\right.$, $7.50 \times 10^{-3}, 1.125 \times 10^{-2}$, and $1.50 \times 10^{-2} \mathrm{molL}^{-1}$ ) in kerosene. The effect of the concentration of TOPO in the organic phase on the extraction of $\mathrm{Fe}(\mathrm{III})$ ions is shown in Figure 10. Furthermore, $\ln \left(C_{o} / C_{e}\right)$ vs time plots are illustrated in Fig.11.

According to Figure 11, the extraction and eluation of $\mathrm{Fe}$ (III) in the different acceptor phase concentration processes conforms to the successive first order reaction kinetics. Extraction efficiency of $\mathrm{Fe}$ (III) ions at different extractant concentration $\left(3.75 \times 10^{-3}, 7.50 \times 10^{-3}\right.$, $1.125 \times 10^{-2}$, and $1.50 \times 10^{-2} \mathrm{molL}^{-1}$ ) is 99.95 , 99.98, 99.96, and \%99.97, respectively. Time of extraction for different TOPO concentration in kerosene $\left(3.75 \times 10^{-3}-1.50 \times 10^{-2} \mathrm{molL}^{-1}\right)$ is 140 , 100, 90, and $80 \mathrm{~min}$, respectively. For four different concentrations of TOPO solution $\left(3.75 \times 10^{-3}-1.50 \times 10^{-2} \mathrm{molL}^{-1}\right)$ in donor phase, $k_{1}$ is $1.72 \times 10^{-2}, 3.49 \times 10^{-2}, 3.41 \times 10^{-2}$, and $3.85 \times 10^{-2}$ $\mathrm{min}^{-1}$, respectively. When the concentration of TOPO was $>3.75 \times 10^{-3}$ the transport of $\mathrm{Fe}$ (III) would decrease with transfer time. 


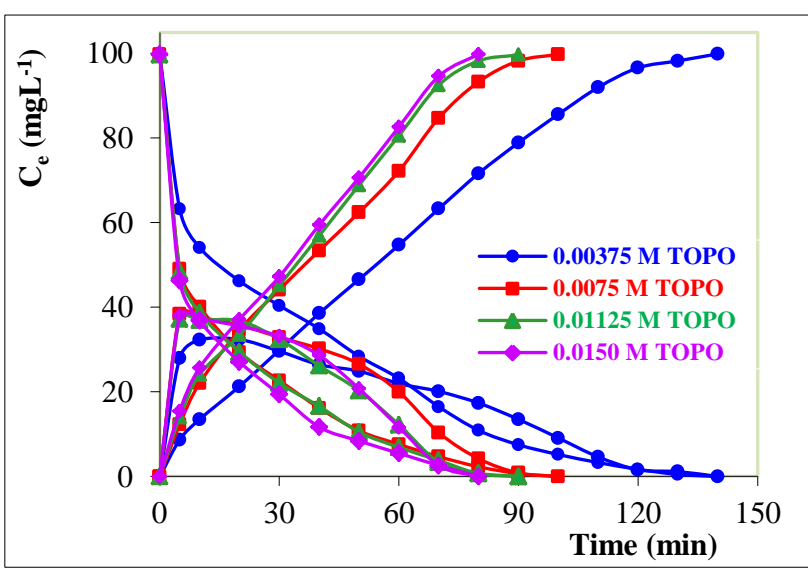

Figure 10. The effect of TOPO concentration in the organic phase on the percent extraction of $\mathrm{Fe}(\mathrm{III})$ ions.

Extraction efficiency of $\mathrm{Fe}(\mathrm{III})$ ions rises with increasing TOPO concentration. However, some deviations were observed in $k_{1}$ values. This may be caused by decreasing the complexation amount of $\mathrm{Fe}$ (III) ions with TOPO in the donor phase as passing through or stripping of $\mathrm{Fe}(\mathrm{III})$ ions could be slowed down the reaction in the acceptor phase. Thus, $3.75 \times 10^{-3} \mathrm{M}$ TOPO concentration for the next parameter was chosen as the most suitable carrier concentration.

We can conclude that the carrier concentration in the organic phase has very important effect on the transport of Fe(III) ions from MDLM system, especially at transport times and flux rates.

\section{CONCLUSION}

Based on the results of the research that has been done, some conclusions can be drawn:

MDLM technology can be used to extract $\mathrm{Fe}(\mathrm{III})$ ions in solution.

The optimum condition that is obtained to extract $\mathrm{Fe}$ (III) ions from the feed solution to obtain $>99 \%$ efficiency are hydrochloric acid concentrations in $2.00 \mathrm{M}$ donor phase, the concentration of TOPO in the organic phase $1.5 \times 10^{-2} \mathrm{M}, \mathrm{NaCl}$ concentrations in $2.00 \mathrm{M}$ acceptor phase, $50 \mathrm{mLmin}^{-1}$ of flux rate at $298.15 \mathrm{~K}$.

As a result; The TOPO ligand has been found to be an effective carrier ligand for the

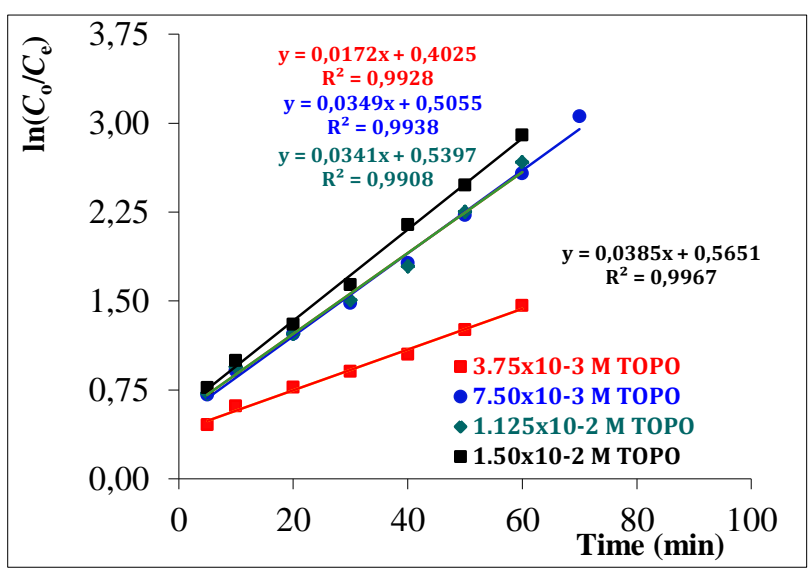

Figure 11. Plots of $\ln \left(C_{\mathrm{o}} / C_{\mathrm{e}}\right)$ vs. time $t$ for the transport of $\mathrm{Fe}(\mathrm{III}))$ ions through the MDLM system at different carrier concentrations.

transport and recovery of $\mathrm{Fe}(\mathrm{III})$ ions. In addition, in the separation and purification of heavy metals, it has been determined that the system is more economical, modular and simple compared to other methods, and it can be used to recover metal ions in optimal conditions in a short time.

\section{REFERENCE}

Alguacil, FJ, Alonso M, 2000. Iron(III) transport using a supported liquid membrane containing Cyanex 921. Hydrometallurgy, 58:81-88.

Alguacil FJ, Martinez S, 2000. Permeation of iron(III) by an immobilised liquid membrane using Cyanex 923 as mobile carrier. Journal of Membrane Science, 176: 249-255.

Alguacil FJ, Alonso M, Lopez FA, LopezDelgado A, Padilla I, Tayibi H, 2010. Pseudo-emulsion based hollow fiber with strip dispersion pertraction of iron(III) using $(\mathrm{PJMTH}+)_{2}\left(\mathrm{SO}_{4}{ }^{2-}\right)$ ionic liquid as carrier. Chemical Engineering Journal, 157:366-372.

Bagheri H, Gholami A, Najafi A, 2000. Simultaneous preconcentration and speciation of iron(II) and iron(III) in water samples by 2-mercaptobenzimidazolesilica gel sorbent and flow injection analysis system. Analytica Chimica Acta, 424:233-242. 
Balkaya T, 2017. Çok Damlacıklı Sıvı Membran ile Dikromat iyonu ekstraksiyonunun incelenmesi, Pamukkale Üniversitesi Fen Bilimleri Enstitüsü, Yüksek Lisans Tezi (Basılmış).

Basuki KT, 2008. Mathematical modeling for the extraction of uranium and molybdenum with emulsion liquid membrane, including industrial application and cost evaluation of the uranium recovery. Jurnal Forum Nuklir, 2(1):63-87.

Biswas RK, Begum DA, 2001. Kinetics of stripping of $\mathrm{Fe}^{3+}$-D2EHP complexes from D2EHPA-kerosene phase by aqueous $\mathrm{HCl}-$ $\mathrm{Cl}^{-}$phase using the single drop technique. Hydrometallurgy, 60:81-97.

Chang SH, Teng TT, Norli I, 2011. Cu(II) transport through soybean oil-based bulk liquid membrane: Kinetic study". Chemical Engineering Journal, 173:352360 .

Comesaña A, Rodriguez-Monsalve J, Francisco AC, Alguacil J, 2011. Non-dispersive solvent extraction with strip dispersion (NDSXSD) pertraction of $\mathrm{Cd}(\mathrm{II})$ in $\mathrm{HCl}$ medium using ionic liquid CYPHOS IL101. Chemical Engineering Journal, 175(15):228-232.

Djunaidi MC, Haris A 2003. Pemisahan logam berat menggunakan membran cair berpendukung dengan variabel konsentrasi ion logam dan ph fasa umpan. Jurnal Kimia Sains \& Aplikasi, 6(2):1-4.

Donat R, Durmaz Ö, Cetişli H, 2015. Transportation and kinetic analysis of Mo(VI) ions through a MDLM system containing TNOA as carrier. Journal of Hazardous Materials, 294:17-26.

Donat R, Durmaz Ö, Cetişli H, 2017. The kinetic analysis of optimization and selective transportation of $\mathrm{Cu}(\mathrm{II})$ ions with TNOA as carrier by MDLM system. Chinese Journal of Chemical Engineering, 25(4):415-425.
Donat R, Eyice Mİ, 2018. Extraction of $\mathrm{Cd}^{2+}$ ions from MDLM System with TNOA carrier. Marmara Fen Bilimleri Dergisi, 4:467-477.

Donat R, Kunter A, Cetişli $\mathrm{H}, 2018 . \mathrm{Mn}^{2+}$ İyonlarının Kerozen İçinde Çözünmüş DİODFA ile geri kazanımı. 13. Ulusal Kimya Mühendisliği Kongresi, 03-06 EYLÜL 2018, Van.

Durmaz O, Donat R, Cetisli H, 2016. Transportation of $\mathrm{Pb}(\mathrm{II})$ ions with D2EHPA as Carrier by MDLM System. International Journal of Innovative Research in Science, Engineering and Technology, 5(12):47-56.

Erden KE, Donat R, Aytaş Ş, 2015. Simultaneous Extraction and Stripping of Uranium Ions via Multi-Dropped Liquid Membrane System. Russian Journal of Applied Chemistry, 88:1902-1912.

Erden KE, Donat R, 2018. Transportation and kinetic analysis of $\mathrm{Zn}$ (II) ions via MDLM system containing D2EHPA as carrier, Membrane Water Treatment, 19(1):23-31.

Eyice Mİ, 2013. Emülsiyon Siv1 Membran Tekniği ile $\mathrm{Cu}^{2+}$ ve $\mathrm{Cd}^{2+}$ İyonlarının Ekstraksiyonunun İncelenmesi, Pamukkale Üniversitesi Fen Bilimleri Enstitüsü, Yüksek Lisans Tezi (Basılmış).

Fu X, Yu L, Lin Y, Zhu H, Wang H, Zhou X, 2004. Structure Adjustment of Mesoporous $\mathrm{ZrO}_{2}$ Prepared with the Middle Phase Formed in Extraction Systems. Solvent Extraction and Ion Exchange, 22(5):885895.

Gheorge A, Stoica A, Floarea O, 2008. Emulsion liquid membranes stability. Universitatea Politechnica Bucuresti Scientific Bulletin, 70(3):23-30.

Gupta VK, Gupta M, Sharma S, 2001. Process development for the removal of lead and chromium from aqueous solutions using red mud-an aluminium industry waste. Water Research, 35:1125-1134. 
Hamzah B, Jalaluddin N, Wahab AW, Upe A, 2011. Pengaruh ion kadmium(II) dan nikel(II) pada ekstraksi ion tembaga(II) dengan ekstraktan 4-benzoil -1-fenil-3metil-2-pirazolin-5-on menggunakan emulsi membran cair. Natur Indonesia, 13(3):269-275.

Jayachandran J, Dhadke PM, 1997. Liquid-liquid extraction separation of iron (III) with 2ethyl hexyl phosphonic acid mono 2-ethyl hexyl ester. Talanta, 44(7):1285-1290.

Kargari A, Kaghazchi T, Sohrabi M, Soleimani M, 2004. Batch extraction of gold(III) ions from aqueous solutions using emulsion liquid membrane via facilitated carrier transport. Membrane Science, 233(1-2):1-10.

Kobya M, Topçu N, Demircioğlu N, 1997. Kinetic analysis of coupled transport of thiocyanate ions through liquid membranes at different temperatures". Journal of Membrane Science, 130:7-15.

Kondo K, Matsumoto M, 1998. Separation and concentration of indium(III) by an emulsion liquid membrane containing diisostearylphosphoric acid as a mobile carrier. Separation and Purification Technology, 13(2):109-115.

Lazarova Z, Boyadzhiev L, 1993. Kinetic aspects of copper(II) transport across liquid membrane containing LIX-860 as a carrier. Journal of Membrane Science, 78:239-245.

Lupi C, Pilone D, 2000. Reductive stripping in vacuum of $\mathrm{Fe}$ (III) from D2EHPA. Hydrometallurgy, 57:201-207.

Nandre KP, Puyad AL, Bhosale SV, Bhosale SV, 2014. A novel donor-acceptor receptor for selective detection of $\mathrm{Pb}(2+)$ and $\mathrm{Fe}(3+)$ ions. Talanta, 130C:103-107.
Othman N, Mat H, Goto M, 2006. Separation of silver from photographic wastes by emulsion liquid membrane system. Membrane Science, 282(1-2):171177.

Patel B, Kumar A, Menon SK, 2009. Liquid Membrane Transport Kinetics of $\mathrm{Hg}$ (II) by Dithio Derivatized Macrotricyclic Compound. Journal of Macromolecular Science R, Part A: Pure and Applied Chemistry, 46:1151-1155.

Pośpiech B, Walkowiak W, Woźniak MJ, 2005. Application of TBP in selective removal of iron(III) in solvent extraction and transport through polymer inclusion membranes processes. Physicochemical Problems of Mineral Processing, 39:89-98.

Praipruke S, Kriausakul K, Tantayanon S, 2012. Extraction of palladium from acidic chloride media into emulsion liquid membranes using LIX 984N-C. Nonferrous Metallurgy, 1:13-22.

Saji John K, Sajin J, Reddy MLP, Ramamohan, TR, Rao TP, 1999. Solvent extraction of titanium(IV) from acidic chloride solutions by Cyanex 923. Hydrometallurgy, 51:918.

Saji J, Reddy MLP, 2001. Liquid-liquid extraction separation of iron(III) from titania wastes using TBP-MIBK mixed solvent system. Hydrometallurgy, 61:8187.

Tavşan E, 2012. Sıvı Membran Tekniği ile Toryumun Ekstraksiyonunun İncelenmesi, Pamukkale Üniversitesi Fen Bilimleri Enstitüsü, Yüksek Lisans Tezi (Basılmış). 